\title{
Investigating the Relationship Between Corporate Entrepreneurship and Customer Loyalty with Customer Satisfaction Mediating Role
}

\author{
Iman Abdel Hamid Hasanin ${ }^{1}$ \\ ${ }^{1}$ Imam Muhammad Bin Saud Islamic University, Riyadh, Saudi Arabia \\ Correspondence: Iman Abdel Hamid Hasanin, Department of Business Administration, Faculty of Economics \\ and Administrative Sciences, Imam Muhammad Bin Saud Islamic University, Riyadh, Saudi Arabia.
}

Received: May 30, 2018 Accepted: September 2, $2018 \quad$ Online Published: November 24, 2018

doi:10.5539/ijms.v10n4p94 URL: https://doi.org/10.5539/ijms.v10n4p94

\begin{abstract}
The study aims to identify the nature of the relationship between the dimensions of corporate entrepreneurship and loyalty of customers. It intends to do that through the mediating role of customer satisfaction, by identifying the extent to which these dimensions apply according to the study the study, as well as the knowledge of the relationship quality. In order to meet the objectives of the study, a regular sample of 384 individuals was selected. These individuals were clients of the selected commercial banks, selected by customers who frequented the banks within a specified period of time.

The study also found that there was a statistically significant correlation between corporate entrepreneurship and customer loyalty, which means that the greater the application of corporate entrepreneurship, the higher the effect of internal and external factors. The study suggests a set of recommendations to encourage banks in the study to apply CE to enhance customer loyalty.
\end{abstract}

Keywords: entrepreneurship, internal entrepreneurship, corporate entrepreneurship, customer loyalty, customer satisfaction, commercial banks

\section{Introduction}

Commercial banks are a key driver that plays an important role in the domestic and international economies. Considering the fact that these banks are important due to their role, they are constantly seeking to develop their practices in order to achieve customers' satisfaction. We now live in an era of increasing interest in entrepreneurship, defined as: a dynamic process involving a mixture of resources, human and otherwise, directed to produce innovative work that involves risk and leads to profit (Hasnin, 2016), where entrepreneurship is currently the main engine and main source of business. And although it needs a special type of founders and employees, the entrepreneur is the one who has what others do not have.

The role of innovation in market development processes, products or both, has emerged as a response to this role. The School of corporate Entrepreneurship has emerged and has responded to organizations' needs for innovation. Many organizations seek to adopt new approaches to improve Customer Satisfaction as well as enhance their relationships with customers by adopting new methods that will increase Customer Satisfaction as well as his loyalty.

Customers Loyalty has been mainly focused on the loyalty to the trade mark concerning material goods as well as the loyalty to the shop. However, many studies have recently started applying that concept in other areas, including adding services where retention costs are much lower than either the relative costs of acquiring a customer or gaining customer loyalty. It is believed that in order to increase annual profits, customers must remain in the organization to build customer loyalty.

In recent years, a direct correlation between an increased interest in marketing research, brand building and customer loyalty has been found, where these customers are the promoters of the organization through the word of mouth and the increase of their purchasing share. Thus, reducing costs, increasing profits and decreasing costs through reducing the costs used in attracting new customers. It's been shown that the cost of losing an existing customer is five times more than the cost of attracting one. 
The concept of loyalty is the focus of both the academics as well as the practitioners in the field of marketing generally and the behavior of the customer particularly. It has been this way for more than fifty years because it is one of the most important elements that are believed to explain the customer's choice of the brand.

Studies have shown that customer satisfaction alone is not enough, because there is no guarantee that the customer who is satisfied will repeat the purchase. This confirms that customer loyalty is more important than satisfaction concerning the success of organizations.

$\mathrm{Li}$ and Zhang, define the concept of loyalty as the focus of attention of all academics and practitioners in the field of marketing in general and consumer behavior in particular, from 50 years to the present (Li \& Zhang, 2010). Despite the interest in loyalty, it was mainly based on loyalty to the trade mark in the field of material goods. However; there are many studies that have recently begun to apply that concept in other areas of industrial business and services (Alsahan, 2000).

Any organization can study the behavior of the client, in order to identify the loyal customer that has true allegiance, to distinguish between them and the customer that has a false allegiance and also determine the conversion rates of the customers from the company to competitors as well as the rates of the complaints and the trends.

Most organizations also recognize the importance of a direct relationship between the high level of Customer Satisfaction and the frequency of the purchase of the customer. Such organizations believe that the higher the level of customer satisfaction, the more necessarily it will increase the amount spent by said client, through the transactions between him and the organization. However, this relationship cannot be relied upon today, as high levels of satisfaction do not necessarily translate into higher sales and profits. This has led to the failure of many organizations. Recently, it has been noted that commercial banks have faced many challenges in the past few years. They are constantly developing their performance and practices by increasing their interest in the concepts of internal entrepreneurship and realizing their role in improving their strategic and competitive capabilities in order to meet the challenges they face. Thus, enhancing its potential and ability to achieve better customer values and thus gain their loyalty. So, the researcher conducted the survey on a sample of bank customers in the study place. This study revealed many findings, including that the commercial banks customers find difficulties in dealing with banks. They complain about these banks failing to exert remarkable efforts to attract them in dealing with them or establishing long-term relationships with them. Therefore, the problem of the research can be identified through a number of questions, as follows:

1) To what extent are the efforts and activities related to corporate entrepreneurship within the banks that are under study.

2) What benefits occur to both banks and their customers in applying the concept of corporate entrepreneurship in the long term and its role in building Customer Satisfaction and Customer Loyalty?

\section{Literature Review}

\subsection{Corporate Entrepreneurship}

The definition provided by Sharma and Chrisman (1999) describes corporate entrepreneurship as follows: [...] the process whereby an individual or a group of individuals, in association with an existing organization, create a new organization, or instigate a renovation or an innovation within that organization. CE is an important means of attraction and a way to sustain the competitiveness of organizations (Covin \& Mills, 1999). Zahra noted that corporate entrepreneurship is the sum total of any company's innovation (Zahra, 1995). Morris and Kuratko stated that CE Is a framework for facilitating continuous change and innovation in existing organizations and representing a blueprint for dealing effectively with everything new under the competitive conditions faced by companies in the global market (Morris \& Kuratko, 2002). The concept of corporate entrepreneurship (CE) has gained great importance in the global economy according to Hornsby et al. (1999). Technological changes, innovations and improvements, all continue leading to the reduction of traditional methods. It has been recognized that corporate entrepreneurship is one of the most important means to enhance competitiveness, manage markets and create value for customers, where senior managers take the lead in institutional leadership, seeing as they are responsible for formulating a strategic vision for entrepreneurship as well as reformulating organizational structures to fit with the requirements of CE. Thus, it is clear that there are many contributions in the field of institutional entrepreneurship, seeing as it's a means of supporting organizations that seek to survive and continue something that is very much related to the level of senior management and the building of the organization's strategies. Ihab pointed out that institutional entrepreneurship has multiple dimensions (Ihab, 2012): 
Frist, establishing corporate projects through the existing organizations making new businesses and projects,

Second, the exploration of Internal Entrepreneurship by offering new ideas and seeking support and application of their ideas (defending ideas / seeking support for ideas),

Third, strategic innovation through the transformative leadership, which is seen through the managing approach to the leadership orientation as well as the development of entrepreneurship strategies and creative management style.

The interest of corporate entrepreneurship began in the mid-1980s, where Gifford Pinchot (1985) noted that corporate entrepreneurship is the leading practice within organizations. Kuratko et al. (1990), on the other hand, saw corporate entrepreneurship as an individual working in a large enterprise, seeking to transform an idea into a product with an end-to-end risk and a creative ability. Corporate entrepreneurship is a way to enable individuals to accomplish their entrepreneurial idea, as it is a bottom-up process. The researchers have pointed out that those bottom-to-top learning tools are often called internal entrepreneurship. Internal business, within multiple management levels, is an important factor in the organization's initiatives and leadership behaviors and is in line with the organization's overall strategy. Corporate entrepreneurship and internal entrepreneurship can be distinguished by looking at corporate entrepreneurship as being closely related to the organization's corporate strategy, when we see that internal entrepreneurship is linked to leading entrepreneurial practices within the organization. Eesley and Longenecker (2006) pointed to the need to view the processes of empowering internal business entrepreneurship as corporate or systemic behavior patterns that are not dependent on the available resources. The organization faces multiple competitive pressures, which it always calls upon and addresses through the development of innovative products, solutions and ideas. Some authors emphasize the need for organizations to encourage both innovation and corporate entrepreneurship within them, adding that successful corporate entrepreneurship requires concentration, which is strong on both the domestic and foreign business environment, with the aim of discovering and investing in business opportunities, that are available at-risk aversion and to achieve the competitive advantage of the leading organization (Platzekst et al., 2010). According to Chang (2000), corporate entrepreneurship is the generation of innovations that is based on the internal resources of the organization and its employees (Ihab, 2012).

\subsubsection{Dimensions of Corporate Entrepreneurship}

Drucker (1992) noted that if the organization has entrepreneurial behavior, the employees can become entrepreneurs. The situation can also become bureaucratic if the organization is itself bureaucratic. Corporate entrepreneurship is a highly complex process that interacts with internal and external regulatory procedures. Studies have also indicated that the financial rewards paid for the good performance of employees may enhance the behavior of individuals and teams towards entrepreneurial performances and innovation especially within manufacturing companies. Entrepreneurial companies are constantly trying to invest regularly in the innovative skills of the staff and teams through training. Results indicate that staff training contributes to organizational innovation (Shipton et al., 2006). Furthermore, results reported by Hayton (2005) and Shipton et al. (2006) confirm.

\subsubsection{Organizational Factors}

\subsection{Entrepreneurial Climate}

According to Kuratko et al. (2014), values and norms within the positive community oblige individuals to internal entrepreneurship. The entrepreneurial climate within the organization is encouraging initiatives, with experience, error and non-phishing being an important element to encourage internal entrepreneurship.

\subsection{Senior Management Support}

Conferring to Kuratko et al. (2014), Management Support refers to the level which the top managers support, enable and encourage entrepreneurial behavior in. Through the provision of moral support, encouragement and appreciation of creative efforts, the process of supporting the administration can be defined, as the readiness of management to support the leadership behavior within the organizations, which includes the promotion of creative ideas as well as providing the human resources necessary to take the pilot actions.

\subsection{Availability of Resources}

Resources, such as those of time, finance as well as material ones are all necessary to discover and implement new business opportunities (Kuratko et al., 1990). Organizational behavior research has proven that resources are critical and important in motivating the staff within organizations in order for them to start and move towards 
creative activities. And while the application of creations is a costly process, it is necessary to work in new ways with the creative staff.

\subsubsection{Individual Factors}

The initiator is not bound by the environmental forces or circumstances but is the one who can deliberately influence or change them. It is expected to show more leadership behaviors within organizations Kuratko et al., 1990; Hornsby et al., 2002). Research has indicated positive relationships between the entrepreneurial personality and many entrepreneurial behaviors, including leadership, entrepreneurship, organizational creativity as well as cognitive aptitude, where leadership behavior can be developed within existing organizations. It's better if a person is distinguished in his work and capable of rapid learning. The cognitive ability of the individual means that the enjoyment of high skills and knowledge will lead to greater internal leadership. Studies have shown that knowledge is essential in generating new ideas. Qualifications which are a measure of knowledge of work and skills are also related to personal initiatives.

\subsection{Customer Loyalty}

Customer loyalty is defined as: "a measure of the degree of re-purchase of a particular trade mark by the customer". It is also known as: "a measure of the customer's willingness to engage in reciprocal utilitarian participation with the company's activities in regard to its products and services" (Kotler \& Scheff, 1997). The loyalty of customers to a commodity or a brand comes from their confidence in the work of the manufacturer of said commodity (Reichheld \& Schefter, 2000).

One of the most widely accepted definitions of loyalty is Oliver's (1997) assertion that the customer has a deep internal commitment to rebuy a commodity or a business service continuously in the future, which leads to a repeat purchase of the same brand or the same set of labels. It has the ability to affect the transformative behavior.

On the other hand, loyalty means the possibility of choosing a particular organization or brand when purchasing a new good or service as well as the possibility of recommending a particular organization or brand when someone else is seeking advice on purchases (Coelho \& Henseler, 2012). Kandampully and Suhartanto (2000) argued that customer loyalty means repurchasing from the service provider or the product itself, where possible, something that still maintains a positive attitude towards the service provider or the commodity itself.

\subsubsection{Kinds of Loyalty}

\subsubsection{Attitudinal Loyalty}

Guest (1944) is the first researcher to suggest that loyalty can be measured in terms of the attitude towards customers by asking one question to respondents: Which of these brands do you prefer most? This approach was later followed by a group of researchers. Loyalty was treated as a state, preference, and intention of purchase. The behavioral aspects of allegiance were mainly the functions of psychological processes affecting the customers (Jacoby, 1971). Many researchers have linked the concept of the term 'loyalty' to different concepts and terminology, such as the relative loyalty of the brand or supplier (Dick \& Basu, 1994; Morais et al., 2004) or the client's psychological attachment to the product (Backman, 1991). Rundle-Thiele (2005) found that there are six measures related to endowment: (1) standards of purchase intent; (2) preference; (3) commitment; (4) the word of mouth; (5) measure of probability of purchase; (6) effect. Despite the broad acceptance of these standards and their suitability by too many studies and within different sectors, loyalty in general has faced many criticisms, notably concerning the fact that it failed to give actual indicators to predict the purchasing behavior of customers. Morris (2002) found that the use of endowment alone does not give a complete picture of customer loyalty and also that it is difficult to explain the psychological aspects of customers and identify the real factors that affect their purchasing decisions.

\subsubsection{Behavioral Loyalty}

Brand loyalty can be seen as a public behavior of a customer towards a particular brand and it shows in the pattern of the purchase frequency patterns. The frequency of the purchase can appear in the actual quantity of the purchase, the number of times a specific brand is purchased compared to the total number of brands purchased, or the actual amount spent on the product. The behavioral dimension of the loyalty reflects the extent of the customers repurchase from the organization and his total purchases of the same product category over a specified period of time (Bove \& Johnson, 2006).

The behavioral side depends on the customer's loyalty to the repurchase behavior, which is evidenced by several measures such as purchase quantity, recent procurement, repeat purchase, follow-up and continuity of purchase 
from the organization as well as the value of product payments for the organization (Auh et al., 2007). Behavioral allegiance can be seen as a result of directional loyalty, since without knowing and understanding the customer's decision-making attitude towards the brand, it is difficult to design marketing programs to modify behavioral allegiance particularly in an unstable environment where needs and circumstances change (Rundle-Thiele, 2005). However, recent studies indicate that a customer may be loyal to a particular store, not a particular brand, and he may be loyal to the service providers, not to the bank itself (Corstjens \& Lal, 2000). believes that no consideration should be given to what is happening in the customer's nervous system, as behavior is the basis for judging the degree of loyalty to the brand. Others believe that behavioral measures of customer loyalty give a clearer picture of brand performance compared to that of its competitors as well as the fact that the data obtained by these researchers are keys as well as sensitive inputs in calculating the value that the customer represents to the organization during its stay with it - that is, the customer lifetime value.

\subsubsection{Dimensions of Loyalty}

\subsubsection{Trust}

Brand loyalty is exhibited through the customer obtaining a guarantee, something which happens in the absence of prior experience and accurate information about the trademark to the consumer regarding the trademark he wants to buy specifically. And by being assured of the right to return what was purchased within a specified period of time or obtaining appropriate guarantees or quotas to receive a commodity and test it over a period of time without charge. Trust is also a major factor in the marketing environment concerning the product market and its customers. His cooperation may be direct. Thus, the behavior of the employees is a key factor in building trust between these employees and customers. The trust level in the customers is based on several factors like staff efficiency as well as how goods or services are provided.

\subsubsection{Commitment}

Commitment is one of the most important variables that leads to loyalty to the brand after the customers trust and satisfaction with the trademark or the marketing process of these brands. Commitment is an attachment and adherence to a certain belief, or value. Here the consumer has an attachment and a loyalty to certain brands or trademarks and is in a mental state that does not change easily but becomes rooted.

\subsubsection{Satisfaction}

Satisfaction is defined as a customer's feeling of happiness or disappointment concerning how the perceived goods meet his expectations. Loyalty is closely related to the satisfaction of the individual with the trademark in the past and is influenced by the mental image that is made up due to the quality of the trademark as well as towards the goals that marketing managers seek to achieve.

\subsection{Relationship Between Corporate Entrepreneurship and Loyalty}

The studies carried out by both companies concerning the study of the internal factors in institutional entrepreneurship concluded that the support of Senior Management, the system of encouragement as well as using the system of rewards and appreciation in the work has a great positive impact on $\mathrm{CE}$, while the organizational structure and the availability of resources have no significant impact on CE (Olughor, 2014); Chen and Cangahuala (2010) focused on a selection of banks in Indonesia which serve as service providing organizations. Technological skills such as modern production systems and product design can be used with CE. Studies have shown that staff retention strategy is closely related to CE and that other factors in the organization's internal environment such as Senior Management support and organizational determinants are also associated with CE. Olughor (2014) focused on telecommunication companies which are also service providing organizations. Chen and Cangahuala (2010) focused in their study about the support of Senior Management. The system of reward and work appreciation is associated with a significant effect on each of the three dimensions of institutional entrepreneurship (innovation - proactivity - risk). The study also concluded that organizational factors have a significant relation to innovation and creativity in the sense that time is related to the statistical significance along with risk. The support of the Senior Management has a strong moral relation with the entrepreneurial orientation. It was also found that the entrepreneurial orientation has a notable relation with the availability of time, work appreciation, rewards and motivation, though the study did not include organizational factors. According to Bhardwaj and Sushil (2012), CE may have several objectives, including gaining strategic renewal, fostering innovativeness as well as gaining international success (Birkinshaw, 1997). Moreover, $\mathrm{CE}$ can be conceptualized as an entrepreneurial activity involving product, process, and organizational innovations (Covin \& Miles, 1999). Ireland, Hitt and Sirmon (2003) found that CE was positively related to the intangible aspects of knowledge, training, job satisfaction and profitability. The study also found 
that the availability of the appropriate internal environment achieves the goals and initiatives of CE. According to Wong et al. (2005), corporate entrepreneurship practices impact the organizational culture as well as individual and organizational values. They stimulate the adoption of corporate entrepreneurial practices, creating new ideas, solutions and knowledge, thus, providing better service to the organization's customers in an effort to increase their loyalty (Soleimani \& Shahnazari, 2013). The research model was based on the four groups that support corporate entrepreneurial practices which are: entrepreneurial characteristics, Human Resources management trends, organizational culture and employee satisfaction. However, a limited number of studies have attempted to explore more rigorous and integrative analysis of the relations between creativity and practices for Human Resource development (Joo et al., 2013). These regulatory practices will improve the performance of employees and provide better service to customers and thus ensure their loyalty.

The following hypotheses are put forward:

H.1 There is no statistically significant relation between the dimensions of corporate entrepreneurship and the customer loyalty of commercial banks.

\subsection{Customer Satisfaction}

Customer satisfaction is an absolute necessity in achieving organizational goals. It is also a fundamental criterion for performance and is an indicator of the excellence of any organization (Gerson, 1993). When the organization achieves customer satisfaction, the customers promote the organization through word of mouth. This is reflected in the attraction of new customers as well as the times of purchase being repeated seeing as the customers are less inclined to go to competitors (Reichheld et al., 1990). Satisfied customers are willing to pay attention to the organizations which satisfy their needs even if they end up paying more. They prefer to remain with the organization rather than face the risks of moving to other services at lower prices (Reichheld et al., 1990).

Conversely, dissatisfied customers often express their feelings behaviorally (Zeelenberg, 2004). Thus, negative and positive trends may affect the profitability of the company where customers move their attitudes and negative feelings to others through social media which can have an even bigger impact than that of the word of mouth positively or negatively affect the company. The results of the research indicated that one unsatisfied customer may pass his or her bad experience to nine other customers (Hoffman \& Bateson, 2010). A bad word of mouth has a negative and harmful effect on the organization. It affects both the organization's reputation and profitability. On the other hand, if the customer's problem is resolved in a satisfied manner, he will transfer his positive experience to five other persons who are likely to deal with the same company as a result of this positive word of mouth (Hoffman \& Bateson, 2010).

\subsubsection{Dimensions of Customer Satisfaction}

CS is the feedback that the customer makes as a result of either satisfaction or dissatisfaction with the service provided, in comparison with the expectations which he had in the service beforehand and can be measured through: the customer satisfaction with the performance of the bank's employees, his satisfaction with the customer service and product quality, the diversity of services provided, the satisfaction with all bank practices and flexibility, the pricing mechanism in the bank for the services provided as well asthe extent of bank branches and ATMs (Andreassen, 1998).

\subsection{Relationship Between Customer Loyalty and Customer Satisfaction}

CS is a fundamental rule of customer loyalty. It is no longer an option but a necessity to build a lasting competitive advantage that enables companies to retain their customers despite intense competition. However, customer satisfaction is not enough, though it is necessary to obtain high levels of satisfaction in order to achieve loyalty to the brand. Two different approaches are used to explain customer satisfaction. The first approach is the result of matching customers' expectations with their perceptions. This method is called the expectancy disconfirmation approach (Parasuraman et al., 1988). This approach suggests that if customers' perceptions are matched with their expectations in a way that makes them satisfied, it positively affects their level of loyalty. However, if the customers' expectations do not match the perceived value, these expectations become uncertain and thus customers are dissatisfied. If the perceived value of the customer exceeds the expectations, the customer will be fully satisfied. The second approach is based on performance, and conceptualized as cumulative post-purchase evaluation (Oliver, 1997). Thus, we can say that customers are satisfied/dissatisfied when their entire experience of the service encounter is satisfactory/unsatisfactory (Johnson et al., 1996).

Customer loyalty is defined as a customer staying in a constant state of preference for a specific brand over others. This occurs when the customer receives the highest levels of satisfaction, thus becoming a satisfied customer (Park et al., 2004). The results of research and studies focused on the importance of customer loyalty 
due to its role in the future growth of any organization (Tsoukatos et al., 2006). Loyalty to the brand is directly related to customer satisfaction, with many studies indicating that customer satisfaction is the basis of loyalty to the brand.

Oliver (1997) indicated that customer satisfaction determines the repurchase, which increases the future profits of the organization. When customers receive a high level of satisfaction, they repeat the purchase, resulting in an increase in customer loyalty and lower customer complaints as well as a good word of mouth. The image of the organization varies depending on the background of each company according to the media coverage as well as the performance of the company. The construction of the image requires a lot of effort and a plenty of time so that a good image can be built and preserved and to avoid the image collapsing overnight.

Corporate image is also an important factor in the evaluation of an organization (or of the services it offers) and serves as an important factor influencing customer satisfaction, brand loyalty (Davies \& Chun, 2002) and repeat patronage (Andreassen \& Lindestad, 1998). The following hypotheses are put forward:

H.2 There is no statistically significant relation between the customer loyalty and the customer satisfaction with the banks.

\subsection{Impact of Customer Satisfaction on Fostering the Relationship Between CE and CL}

Customer satisfaction is one of the key drivers for customer loyalty development and is an important foundation for delivering the right products to the right customer at the right time (Parasuraman, Zeithaml, \& Berry, 1988). Thus, delivering value to customers is a way for an organization to build its competitive advantage (Ulaga \& Chacour, 2001)

Entrepreneurial attitude among employees is shown through enhancing cooperation, commitment, learning and creativity. Customer satisfaction levels play a role in the relation between corporate leadership and customer loyalty. In general, they have a supportive role for organizational stability through knowledge, management, organizational capacity and increased organizational learning (Theriou \& Chatzoglou, 2008). Employment and selection, payment, job design and team working are all positively related to employee creativity (Jiang et al., 2012). Structuring of HRM is negatively associated with perceived uncertainty and stress. perceptions produce a sense of psychological availability, which in turn enhances employee creativity (Binyamin \& Carmeli, 2010) as well as the level of corporate entrepreneurship within an organization. A similar study identified five successful practices conducive to $\mathrm{CE}$ such as: a fair system of rewards, commitment to Senior Management, resources being available for creativity, organizational learning as well as task forces and risk management culture (Srivastava \& Agrawal, 2010). The study found that the team spirit, the commitment to the management as well as the empowerment of the workers are important factors in the institutional leadership. It also found that the improvement of the customer service, the superiority of the competitors (proactive in entrepreneurship) and loyalty will be achieved through high levels of satisfaction.

The following hypotheses are put forward:

H.3 There is no statistically significant relation between corporate entrepreneurship and the customer satisfaction within the banks customers.

H.4 There is no statistically significant relation between corporate entrepreneurship and customer loyalty with a mediated customer satisfaction towards the banks. 


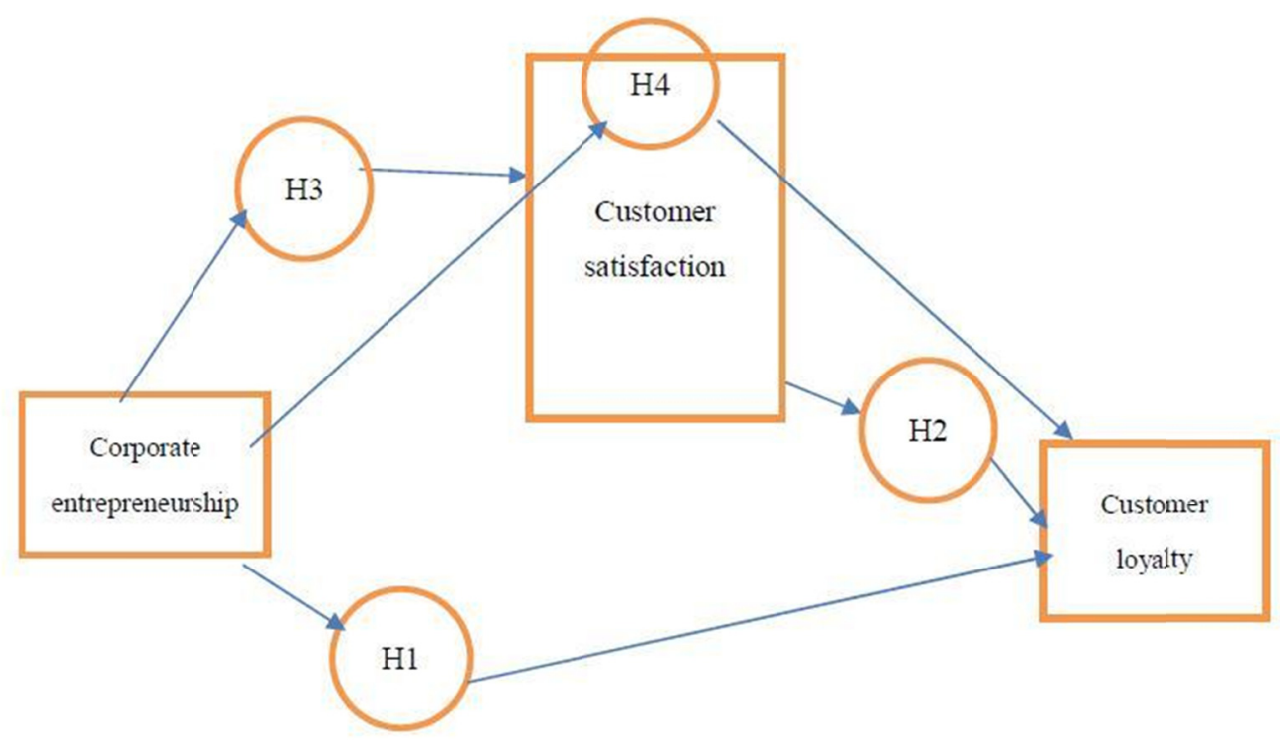

Figure 1. Model of the study with the dependent, the mediator and the independent variables

\section{Methods}

\subsection{Sample Characteristic}

The sample was selected from customers who were interested in commercial banks. According to the Commercial Banks Gide, the research community is more than 100,000. Accordingly, a regular class of 384 was chosen with a $5 \%$ faulty limit and a $95 \%$ trust factor based on financial reports of commercial banks at the end of 2016, the amount of customer deposits in public commercial banks exceeded twice the amount of customer deposits in commercial banks. The sample was distributed at 2: 1 and the response rate was $95.8 \%$. The researcher presents the study method through: the required data and sources, the study and sample population, the study tool and data collection methods as well as measuring the study variables.

The study required secondary data, represented in a theoretical framework concerning the variables of the study, namely: corporate entrepreneurship and customer loyalty. This framework was obtained by reviewing the books and studies that deal with these variables. In order to obtain these data, the researchers consulted the scientific libraries that are specialized in the subjects related to the study. The researcher also referred to the electronic databases available as well as the websites of scientific research in the specified field.

Reliability analysis: It has been used to make sure that the sentences used give the investigated the same meaning and concept as intended by the researcher, are closely related to what is intended to be measured and that the search tool has included all the variables that must be available in theory.

Stability analysis: To measure the stability of the survey lists as a data collecting tool, the Alpha Cronbach method (1) was used, as in Table 1, and if the alpha coefficient value was more than $80 \%$, we can then consider it consistent. This metric refers to the multivariate measurements where alpha is used in the Likert scale and then collected for a compound scale bug where alpha is based on the average correlation of all the scale elements.

Table 1. Reliability and stability analysis

\begin{tabular}{ll}
\hline Variables & Alpha Cronbach \\
\hline Organizational aspects of CE & 0.82 \\
Individual aspects of CE & 0.77 \\
Behavioral Loyalty & 0.84 \\
Attitudinal Loyalty & 0.81 \\
Customer satisfaction & 0.87 \\
\hline
\end{tabular}




\subsection{Descriptive Statistics for Sample Study and Characteristics of Customers of the Understudy Banks}

Table 2. Distribution of the study sample according to the qualifications of the study

\begin{tabular}{lll}
\hline Qualifications variant & Frequency & Ratio \\
\hline Without qualification & 78 & $0.24 \%$ \\
Average qualification & 56 & $0.17 \%$ \\
High qualification & 140 & $0.43 \%$ \\
above High & 51 & $0.17 \%$ \\
Total & 325 & $100 \%$ \\
\hline
\end{tabular}

The results of the statistical analysis, as shown in Table 2 , show that $43 \%$ of the customers of the banks in question are highly qualified, $24 \%$ are qualified, while $17 \%$ have average qualifications.

Table 3. Distribution of the study according to the variable of income

\begin{tabular}{lll}
\hline Income variable & Frequency & Ratio \\
\hline Less than LE 1000 & 64 & $0.20 \%$ \\
$1000-5000$ & 144 & $0.44 \%$ \\
$5000-10000$ & 107 & $0.33 \%$ \\
More than 10,000 & 10 & $0.03 \%$ \\
Total & 325 & $100 \%$ \\
\hline
\end{tabular}

As shown in Table 3, we find that $44 \%$ of the sample respondents are fall under the category of income of 1000-5000, which is a realistic percentage. This indicates that most of the customers of the commercial banks are of middle income and can be attributed to the inclusion of this segment as being among the middle-income classes. The table shows that $33 \%$ of the customers of the understudy banks are from the 5,000-10,000 income categories. Only $3 \%$ of the high-income population indicates that the sample is representative of all income groups.

Table 4. Distribution of the study according to the variable of gender

\begin{tabular}{lll}
\hline Gender Variable & Frequency & Ratio \\
\hline Male & 228 & $0.70 \%$ \\
Female & 97 & $0.30 \%$ \\
Total & 325 & $100 \%$ \\
\hline
\end{tabular}

Table 4 refers to the sample of the study distributed among males and females. The sample representing the society from which it was withdrawn, where we find that $70 \%$ are males and $30 \%$ are females.

Table 5. Distribution of the study according to the years spent dealing with the bank

\begin{tabular}{lll}
\hline Frequency of Dealing Years & Frequency & Ratio \\
\hline Less than 5 years & 78 & $0.24 \%$ \\
$5-10$ years & 56 & $0.17 \%$ \\
10 - 20 years & 140 & $0.43 \%$ \\
More than 20 years & 51 & $0.17 \%$ \\
Total & 325 & $100 \%$ \\
\hline
\end{tabular}

The results of Table 5 indicate that $43 \%$ of the sample study results of dealing with the bank range from 10 to 20 years, increasing the reliability of the results due to the continuous interaction with the bank by the clients. The results of the analysis showed that $24 \%$ of the sample study's customers deal with the bank for less than 5 years while $17 \%$ of them have been dealing with it for more than 20 , indicating that the sample is representative of all categories. 


\section{Results}

In the first model of CFA, elements that measure the variables of the study (EC, CS and CL) were included and the appropriate models were assumed through three indicators CFI, RMSEA, RATIO, and the statistical package program (SPSS.22) was used to analyze the statistical data, using qualitative analysis as well as quantitative analysis. Simple correlation analysis was used for the Pearson correlation. Simple and AMOS 22 were also used.

Table 6. Model fit index

\begin{tabular}{llc}
\hline Absolute Fit Index (AFI) & \multicolumn{2}{l}{ Incremental Fit Index (IFI) } \\
\hline CMIN-DF $=2.148$ & IFI $=0.847$ & CFI $=0.857$ \\
RMSEA $=0.061$ & NFI $=0.805$ & TLI $=0.936$ \\
GFI $=0.801$ & & \\
\hline
\end{tabular}

Through table 6 we find that the absolute correlation indicators have good values with a value of CMIN/DF $=2.148$, which is less than 5. The other indicators exceeded the required ratio of .09. Thus, the model is characterized by the quality of conformity and can be relied upon in testing the proposed research model.

Table 7. EFA, CFA, Cronbach values of the research variables

\begin{tabular}{|c|c|c|c|c|c|c|c|}
\hline $\begin{array}{l}\text { Variables } \\
\text { Corporate entrepreneurship }\end{array}$ & (EFA) & (CFA) & $\begin{array}{l}\text { variables } \\
\text { reliability } \\
\text { (a) }\end{array}$ & (AVE) & (KMO) & \multicolumn{2}{|c|}{$\begin{array}{l}\text { Bartlett's test of } \\
\text { sphericity }\end{array}$} \\
\hline Organizational elements & 0.761 & 0.645 & 0.885 & 75.867 & 0.621 & Chi & 421.57 \\
\hline Individual elements & 0.818 & 0.801 & & & & Sig & 0.000 \\
\hline \multicolumn{8}{|l|}{ Customer satisfaction } \\
\hline Satisfaction with all Bank practices and flexibility & 0.691 & 0.482 & 0.722 & 75.359 & 0.711 & & \\
\hline $\begin{array}{l}\text { Customer satisfaction with the performance of the } \\
\text { Bank's employees }\end{array}$ & 0.754 & 0.841 & & & & Chi & 417.63 \\
\hline Satisfaction with customer service and product quality & 0.702 & 0.540 & & & & & \\
\hline $\begin{array}{l}\text { Pricing mechanism in the Bank for the services } \\
\text { provided }\end{array}$ & 0.765 & 0.616 & & & & Sig & 0.000 \\
\hline \multicolumn{8}{|l|}{ Customer loyalty } \\
\hline Behavioral loyalty & 0.715 & 0.672 & 0.815 & 71.207 & 0.825 & Chi & 974.51 \\
\hline Attitudinal loyalty & 0.814 & 0.573 & & & & Sig & 0.000 \\
\hline
\end{tabular}

We can see from Table 7 that the fit of the model is appropriate. Calculated Chi-square is 421.57 significant with $(\mathrm{DF}=106, \mathrm{~N}=338)$, then the percentage of Chi-square $\mathrm{DF}=2.761$ is less than the cut-off value of 3 . Then, as indicated in Table 6 CFI 0.801 , CFI $=0.857$, NFI 0.805 , GFI $=0.801$ are all greater than the recommended value of 9 which means being a good fit and within the standard level. RMSEA $=0.61$., as shown in table 8 and table 9 . The impact of CE on CL is significantly positive with the regression coefficient being (0.763) at P-value 0.000 , thus $\mathrm{H} 1$ is supported. It is shown that the application of corporate entrepreneurship affects the loyalty of customers positively, which means that the understudy banks should expand the application of concepts and dimensions of corporate entrepreneurship, because it has a positive significant on achieving CL. While the impact of CE on CS has a positive significant, the regression coefficient was (0.746) at 0.000. This refers to H2 is supported. Table 9 also indicates that there a positive significant between $\mathrm{CE}$ and $\mathrm{CS}$. The regression coefficient was $(0.541)$ at $\mathrm{p}=0.000$ so $\mathrm{H} 3$ was supported. Finally, table 10 shows that the total effect of EC on CL is 0.61 and significant with the indirect effect being (0.811) and larger than the direct one (0.763). As indicated in table 10 , the regression weight for the path CE to CS to CL is 0.811 with $\mathrm{P}=0.000$, it is shows role of CS between EC and CL. Thus, H4 is supported.

Table 8. Correlation coefficient between variables

\begin{tabular}{llll}
\hline Variables & 1 & 2 & 3 \\
\hline $\mathrm{CE}$ & 0.81 & & \\
$\mathrm{CL}$ & 0.528 & 0.82 & \\
$\mathrm{CS}$ & 0.656 & 0.624 & .087 \\
\hline
\end{tabular}


Table 9. Key Parameters of the structural model

\begin{tabular}{lllllll}
\hline Path & & & hypothesis & Reg. coff. & T -value & p-value \\
\hline $\mathrm{CE}$ & $\longrightarrow$ & $\mathrm{CL}$ & $\mathrm{H} 1$ & .0763 & 10.701 & 0.000 \\
$\mathrm{CL}$ & $\longrightarrow$ & $\mathrm{CS}$ & $\mathrm{H} 2$ & 0.746 & 4.261 & 0.000 \\
$\mathrm{CE}$ & $\longrightarrow$ & $\mathrm{CS}$ & $\mathrm{H} 3$ & 0.541 & 1.406 & 0.000 \\
$\mathrm{CE} \longrightarrow \mathrm{CS} \longrightarrow \mathrm{CL}$ & $\mathrm{H} 4$ & 0.811 & 4.229 & 0.000 \\
\hline
\end{tabular}

Table 10. Direct and Indirect Effect of CL

\begin{tabular}{|c|c|}
\hline Direct, Indirect and Total Effect & Regression weights \\
\hline \multicolumn{2}{|l|}{ Direct effect } \\
\hline $\mathrm{CE} \longrightarrow$ & .0763 \\
\hline $\mathrm{CL} \longrightarrow$ & 0.746 \\
\hline $\mathrm{CE} \longrightarrow \mathrm{CS}$ & 0.541 \\
\hline \multicolumn{2}{|l|}{ Indirect effect } \\
\hline $\mathrm{CE} \longrightarrow \mathrm{CS} \longrightarrow \mathrm{CL}$ & 0.811 \\
\hline \multicolumn{2}{|l|}{ Total effect } \\
\hline $\mathrm{CE} \quad \longrightarrow$ & 0.61 \\
\hline
\end{tabular}

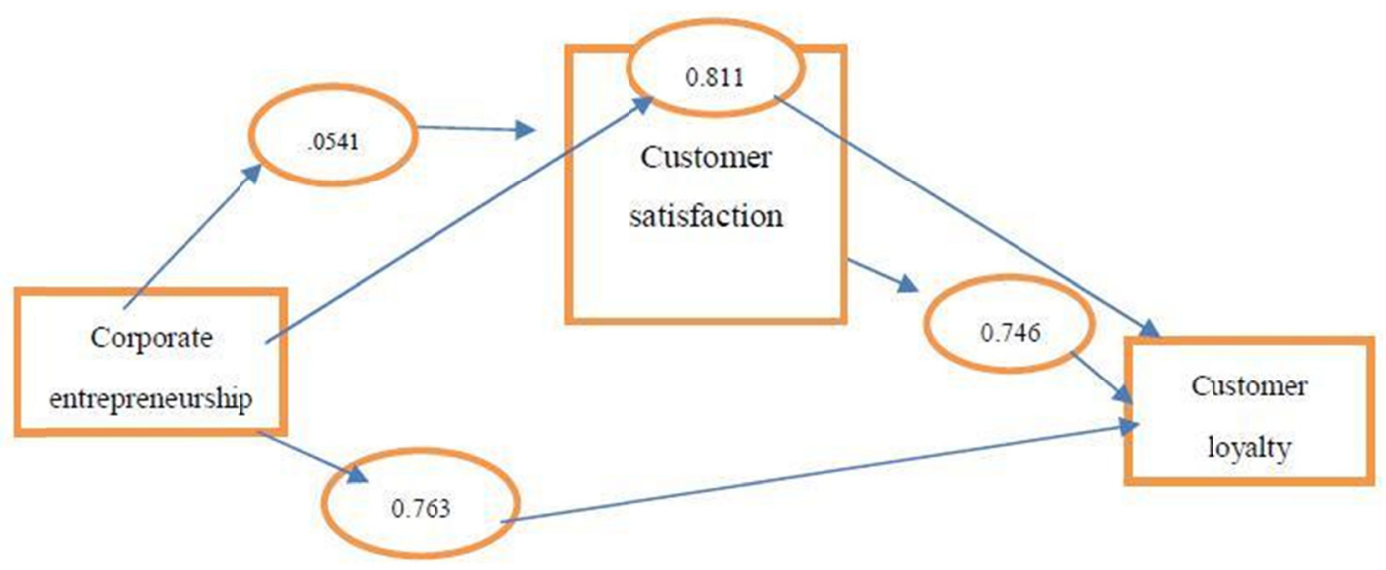

Figure 2. The final conceptual model of the study

\section{Discussion and Conclusion}

The results of the statistical analysis demonstrated the validity of the hypothesis of the study. Accordingly, it can be said that the use and application of the corporate entrepreneurship approach will contribute to increasing the loyalty of the customers. The results indicate that the correlation coefficients have witnessed a significant decline.

Secondly, it is necessary to emphasize the importance of $t$ building a long trusting relationship with the customers, in view of the importance of banking services and the desire to retain the bank customers and also in view of the importance of Human Resources. Not to mention, the most important first-tier employees dealing with customers in the provision of banking services, as part of the service as well as the encouragement of the bank's employees in customer service and providing them with initiatives to achieve customer satisfaction. All of this will be reflected in the customer's confidence in the bank and thus earns their loyalty.

This requires the bank to motivate and train employees. It's also essential to encourage ideas and initiatives in order to create a positive work environment, a balanced climate and to provide all the necessary tools for everyone to carry out their work. Banks must be aware that the concept of loyalty is multidimensional.

Finally: The need to analyze the situational and behavioral dimensions of customer loyalty must be emphasized in order to build more realistic loyalty programs and emerge from the customer's perspective. 


\section{Future Research}

Studying the impact of social entrepreneurship on commercial banks customer loyalty as well as studying the impact of $\mathrm{CE}$ on $\mathrm{CL}$ with a mediating of customer engagement or the customers value. The study can be conducted on another sector that offers a specific subject, such as electric equipment. The study was applied to customers of commercial banks and therefore it can be applied to bank employees in order to identify different points of view as well as different results.

\section{References}

Alsahan, F. M. (2000). Measuring Brand Loyalty. 2nd Annual Scientific Conference: Recent Trends in Business Management.

Andreassen, W., \& Lindestad, B. (1998). Customer loyalty and complex services: The impact of corporate image on quality, customer satisfaction and loyalty for customers with varying degrees of service expertise. International Journal of Service Industry Management, $9(1), \quad 7-23$. https://doi.org/10.1108/09564239810199923

Auh, S. et al. (2007). Co-production and customer loyalty in financial services. Journal of Retailing, 83(3), 359-370. https://dx.doi.org/10.1016/j.jretai.2007.03.001

Backman, J. S. (1991). An Investigation of the Relationship Between Activity Loyalty and Perceived Constraints. Journal of Leisure Research, 23(4), 332-344. https://dx.doi.org/10.1080/00222216.1991.11969864

Bhardwaj, B. R., \& Sushil. (2012). Internal environment for corporate entrepreneurship: Assessing CEAI model for emerging economies. Journal of Chinese Entrepreneurship, 4(1), 70-87. https://doi.org/10.1108/17561391211200948

Binyamin, G., \& Carmeli, A. (2010). Does structuring of human resource management processes enhance employee creativity? The mediating role of psychological availability. Human resource Management, 49(6). https://doi.org/10.1002/hrm.20397

Birkinshaw, J. (1997). Entrepreneurship in multinational corporations: the characteristics of subsidiary initiatives. Strategic Management Journal, 18, 207-229. https://doi.org/10.1002/(SICI)1097-0266

Bove, L. L., \& Johnson, L. W. (2006). Customer loyalty to one service worker: Should it be discouraged?. International Journal of Research in MarketingI, 23(1), 79- 91. https://dx.doi.org/10.1016/j.ijresmar.2006.01.007

Chen, M. H., \& Cangahuala, G. (2010). Corporate entrepreneurship environment and organizational performance in technology manufacturing sector. Proceedings of the Technology management for global economic growth. Phuket, Thailand (July 18-22). Retrieved from http://nchu.creatop.com.tw/upfiles/ADUpload/oc_downmul2339104156.pdf

Coelho, P. S, \& Henseler, J. (2012). Creating customer loyalty through service customization. European Journal of Marketing, 46(3/4).

Corstjens, M., \& Rajiv, L. (2000). Building Store Loyalty Through Store Brands. Journal of Marketing Research, 37(3), 281-291. https://doi.org/10.1509/jmkr.37.3.281.18781

Covin, J. G., \& Miles, M. P. (1999). Corporate Entrepreneurship and the Pursuit of Competitive Advantage. Entrepreneurship Theory and Practice, 24(1), 47-63. https://doi.org/10.1177\%2F104225879902300304

Davies, G., \& Chun, R. (2002). Gaps Between the Internal and External Perceptions of the Corporate Brand. Corporate Reputation Review, 5(2-3), 144-158. https://doi.org/10.1057/palgrave.crr.1540171

Dick, A. S., \& Basu, K. (1994). A customer loyalty: Toward an integrated conceptual framework. Journal of the Academy of Marketing Science, 22(2), 99-113.

Drucker, P. (1992). The New Society of Organizations. Harvard Business Review, September-October, 95-104.

Eesley, D. T., \& Longenecker, C. O. (2006). Gateways to Intrapreneurship. Industrial Management, 48, 1-18.

Gerson, R. S. (1993). Measuring Customer Satisfaction. Crisp Publications.

Guest, L. (1944). A Study of Brand Loyalty. Journal of Applied Psychology, 28, 16-27.

Hasnin, I. A. (2016). The Impact of Entrepreneurial Marketing Behavior on Customer Relationship Management: An Applied Study on Mobile Phone Customers in Egypt. Journal of Marketing and Consumer Research, 41. 
Hoffman, K. D., \& Bateson, J. E. G. (2010). Services Marketing: Concepts, Strategies, \& Cases. Thomson/South-Western.

Hornsby, J. S., \& Kuratko, D. F. (2002). Middle Managers' Perception of the Internal Environment for Corporate Entrepreneurship: Assessing a Measurement Scale. Journal of Business Venturing, 17(3), 253-273. https://doi.org/10.1016/S0883-9026(00)00059-8

Hornsby, J. S., Kuratko, D. F., \& Montagno, R. V. (1999). Perception of internal factors for corporate entrepreneurship: a comparison of Canadian and U.S. managers. Entrepreneurship: Theory \& Practice, 24(2), 9-25.

Ihab, S. Z. (2012). Role of Internal Entrepreneurship in Improving the Strategic Capabilities of the Banking Sector. Ph.D. Thesis, Amman Arab University.

Ireland, R. D., Hitt, M. A., \& Sirmon, D. G. (2003). A Model of Strategic Entrepreneurship: The Construct and its Dimensions. Journal of Management, 29(6), 963-989. https://doi.org/10.1016/S0149-2063(03)00086-2

Jacoby, J. (1971). A Model of Multi-Brand Loyalty. Journal of Advertising Research, 11(3), 25-61.

Jiang, K. et al. (2012). How Does Human Resource Management Influence Organizational Outcomes? A Meta-Analytic Investigation of Mediating Mechanisms. The Academy of Management Journal, 55(6), 1264-1294. https://doi.org/10.5465/amj.2011.0088

Johnson, M. D., Nader, G., \& Fornell, C. (1996). Expectations, perceived performance, and customer satisfaction for a complex service: The case of bank loans [Electronic version]. Cornell University, School of Hospitality Administration.

Joo, B-K. et al. (2013). Creativity and Human Resource Development: An Integrative Literature Review and a Conceptual Framework for Future Research. Human Resource Development Review, 12(4), 390-421. https://doi.org/10.1177/1534484313481462

Kandampully, J., \& Suhartanto, D. (2000). Customer loyalty in the hotel industry: the role of customer satisfaction and image. International Journal of Contemporary Hospitality Management, 12(6), 346-351. https://doi.org/10.1108/09596110010342559

Kotler, P., \& Scheff, J. (1997). Standing Room Only: Strategies for Marketing the Performing Arts. Boston: Harvard Business School Press.

Kuratko, D. F., Covin, J. G., \& Hornsby, J. S. (2014). Why implementing corporate innovation is so difficult. Business Horizons, 57(5), 647-655.

Kuratko, D. F., Montagno, R. V., \& Hornsby, J. S. (1990). Developing an intrapreneurial assessment instrument for an effective corporate entrepreneurial environment. Strategic Management Journal, 11, Special Issue: Corporate Entrepreneurship, 49-58.

Li, Q., \& Zhang, Z. (2010). A theoretical and empirical research on the mediating effect of internal entrepreneurial environment. Journal of Chinese Entrepreneurship, 2(1), 5-18. https://doi.org/10.1108/17561391011018998

Morais, D. B., Dorsch, M. J., \& Backman S. J. (2004). Can Tourism Providers Buy Their Customers' Loyalty? Examining the Influence of Customer-Provider Investments on Loyalty. Journal of Travel Research, 42(3), 235-243. https://doi.org/10.1177/0047287503258832

Morris, M. H., \& Kuratko, F. (2002). Corporate Entrepreneurship: Entrepreneurial Development Within Organizations. Harcourt College Publishers.

Oliver, R. L. (1997). Customer delight: Foundations, findings, and managerial insight. Journal of Retailing, 15, 1-15. https://doi.org/10.1016/S0022-4359(97)90021-X

Olughor, R. J. (2014). The Influence of Organisational Culture on Firms' Effectiveness. IOSR Journal of Business and Management, 16(6), 67-70.

Parasuraman, A., Zeithaml, V. A., \& Berry, L. (1988). SERVQUAL: A multi-item scale for measuring consumer perceptions of service quality. Journal of Retailing, 64(3), 12-40.

Park, N. et al. (2004). Strength of character well-being. Journal of Social and Clinical Psychology, 23(5), 603-619.

Pinchot, G. (1985). Intrapreneur: Why You Don't Have to Leave the Corporation to Become an Entrepreneur. Retrieved from https://ssrn.com/abstract=1496196. 
Platzekst, B., Pretorius, L., \& Winzker, D. (2010). A role model for entrepreneurial firms in a global business environment. Proceedings of the 6th International Scientific Conference, Business and Management. Retrieved from http://www.vgtu.lt/en/editions/proceedings

Reichheld, F. F., \& Schefter, P. (2000). E-Loyalty: Your Secret Weapon on the Web. Harvard Business Review, $78,105-113$

Reichheld, W., Frederick, F., \& Earl Sasser, Jr. (1990). Zero Defections: Quality Comes to Services. Harvard Business Review, 68(5).

Rundle-Thiele, S. (2005). Loyalty: An Empirical Exploration of Theoretical Structure in Two Service Markets. Unpublished Ph.D. Dissertation, University of South Australia. https://doi.org/10.1108/08876040510625990

Sharma, P. \& Chrisman, J. (1999). Toward a Reconciliation of the Definitional Issues in the Field of Corporate Entrepreneurship. Entrepreneurship Theory and Practice, 23(3), 11-27. https://doi.org/10.1007/978-3-540-48543-8_4

Shipton, H., Fay, D., West, M., Patterson, M., \& Birdi, K. (2006). Managing People to Promote Innovation. Creativity and Innovation Management. https://dx.doi.org/10.1111/j.1467-8691.2005.00332.x

Soleimani, M., \& Shahnazari, A. (2013). Studying Effective Factors on Corporate Entrepreneurship: Representing a Model. Journal of Applied Sciences, Engineering and Technology, 5(4), 1309-1316. https://dx.doi.org/10.19026/rjaset.5.4866

Srivastava, N., \& Agrawal, A. (2010). Factors Supporting Corporate Entrepreneurship: An Exploratory Study. Vision: The Journal of Business Perspective, 14(3). https://doi.org/10.1177/097226291001400302

Theriou, G. N., \& Chatzoglou, D. P. (2008). Enhancing performance through best HRM practices, organizational learning and knowledge management: A conceptual framework. European Business Review, 20(3), 185-207. https://doi.org/10.1108/09555340810871400

Tsoukatos, E., \& Rand, G. K. (2006). Path analysis of perceived service quality, satisfaction and loyalty in Greek insurance. Managing Service Quality: An International Journal, 16(5), 501-519. https://doi.org/10.1108/09604520610686746

Ulaga, W., \& Chacour, S. (2001). Measuring Customer-Perceived Value in Business Markets. Journal of Industrial Marketing Management, 30, 525-540.

Wong, P., Ho, Y., \& Singh, A. (2005). Towards an entrepreneurial university model to support knowledge-based economic development: the case of the national university of Singapore. World Development, 35(6), 942-958. https://doi.org/10.1016/j.worlddev.2006.05.007

Zahra, S. A. (1995). Corporate entrepreneurship and financial performance. The case of management leveraged buyouts. Journal of Business Venturing, 10(3), 225-247. https://doi.org/10.6007/IJARBSS/v4-i1/534

Zeelenberg, M. (2004). Beyond valence in customer dissatisfaction: A review and new findings on behavioral responses to regret and disappointment in failed services. Journal of Business Research, 57(4), 445-455. https://doi.org/10.1016/S0148-2963(02)00278-3

\section{Copyrights}

Copyright for this article is retained by the author, with first publication rights granted to the journal.

This is an open-access article distributed under the terms and conditions of the Creative Commons Attribution license (http://creativecommons.org/licenses/by/4.0/). 